\title{
Effects of Sandimmun on T lymphocyte and dendritic cell subpopulations in psoriasis
}

\author{
B. S. Baker, L. Fry, and A. V. Powles \\ Department of Dermatology, St. Mary's Hospital, London W2, UK
}

Key words: Sandimmun - Psoriasis - T lymphocytes Dendritic cells

Editor,

We would like to point out an error made by Gupta et al. [Archives of Dermatological Research (1989) $281: 219$ 226] when describing a similar study carried out by us [Baker et al., British Journal of Dermatology (1987) $116: 503]$ to investigate the effects of Sandimmun on T lymphocyte and dendritic cell subpopulations in psoriasis. It was stated that we had looked at changes in immune cell types in psoriatic lesions treated with
Sandimmun at time intervals ranging between 10 and 90 days after Sandimmun therapy. In fact, we had studied biopsies at 3 and 7 days (which is at the same time that Gupta et al. took their early biopsies) before clinical treatment was apparent, in addition to those taken at 2 , $3,4,6,8$, and 12 weeks of treatment. Thus, the study by Gupta et al. differed very little from the one carried out by us 2 years previously, apart from the use of much higher doses of Sandimmun - 14 compared to $3 \mathrm{mg} / \mathrm{kg}$ per day in our study. It should be stressed that a dose of $14 \mathrm{mg} / \mathrm{kg}$ per day is unnecessarily high to clear psoriasis and will produce a greater incidence of serious side-effects. A dose of $3 \mathrm{mg} / \mathrm{kg}$ per day is usually sufficient to improve psoriasis and, it is of interest to note, produces an effect on $T$ lymphocytes and dendritic cells that is similar to the higher dose.

\section{Reply}

\author{
A. K. Gupta, O. Baadsgaard, C. N. Ellis, J. J. Voorhees, and K. D. Cooper \\ Department of Dermatology, University of Michigan Medical Center, Ann Arbor, MI 48109, USA
}

\section{Editor,}

We agree with Baker et al. that the optimum dose of oral cyclosporin for the treatment of psoriasis is significantly lower than $14 \mathrm{mg} / \mathrm{kg}$ per day. The study in which Ellis et al. [2] used cyclosporin A (14 mg/kg per day) was the first double-blind, randomized, placebo-controlled study that demonstrated the effectiveness of cyclosporin $\mathrm{A}$ in plaque-type psoriasis. It was never intended to demonstrate the optimum cyclosporin dosage for plaque-type psoriasis.

We disagree with the implication that the data reported in our paper [3] were presented in the study previously published by Baker et al. [1]. Although they allude to having studied biopsies as early as 3 days following therapy, no such data were presented by them [1]. They provide data from only one patient at time points prior to week 12 and only addressed cells expressing CD1 and HLA-DR in that patient. Grouped data on various cell types were presented only for the pretherapy and week 12 time points [1].

Our study differed substantially from that of Baker et al. [1] in that we provided grouped statistical data on changes occurring 7 days following the onset of therapy.
Furthermore, we have provided grouped data on additional immuno-competent cell types, including $\mathrm{CD}^{-}{ }^{-}$$\mathrm{DR}^{+}$subsets such as monocytes and $\mathrm{DR}^{+}$keratinocytes. The reduction in numbers of both epidermal and dermal antigen-presenting cells and $\mathrm{T}$ cells observed by Baker et al. [1] at 12 weeks was definitively shown by us to be statistically significant as early as after 7 days of cyclosporin therapy.

Taken together, these complementary studies support the concept that immune dysregulation is present in untreated psoriasis. We confirm and extend the earlier study by Baker et al. showing that a decrease in immune cell types, in particular non-Langerhans $\mathrm{CD} 1^{-} \mathrm{DR}^{+}$cells, occurs early and progressively in the course of cyclosporin therapy and correlates with clinical clearing of lesions.

\section{References}

1. Baker BS, Griffiths CEM, Lambert S, Powles AV, Leonard JN, Valdimarsson H, Fry L (1987) The effects of cyclosporin A on T 
lymphocyte and dendritic cell sub-populations in psoriasis. Br J Dermatol 116:503 - 510

2. Ellis CN, Gorsulowsky DC, Hamilton TA, Billings JK, Brown MD, Headington JT, Cooper KD, Baadsgaard O, Duell EA, Annesley TM, Thurcotte JG, Voorhees JJ (1986) Cyclosporine improves psoriasis in a double-blind study. JAMA 256:31103116
3. Gupta AK, Baadsgaard O, Ellis CN, Voorhees JJ, Cooper KD (1989) Lymphocytes and macrophages of the epidermis and dermis in lesional psoriatic skin, but not epidermal Langerhans cells, are depleted by treatment with cyclosporine A. Arch Dermatol Res $281: 219-226$ 